\title{
Effectiveness of alternative herbicides on three Conyza species from Europe with and without glyphosate resistance
} \author{
Rafael De Prado ${ }^{\mathrm{b}}$ \\ a Department of Agronomy and Plant Breeding, University of Mohaghegh Ardabili, Ardabil, 56131-56491, Iran \\ b Department of Agricultural Chemistry and Edaphology, University of Cordoba, 14071, Cordoba, Spain \\ ${ }^{\mathrm{c}}$ Departamento de Fitotecnia, Universidade Federal de Viçosa, 36570-900, Viçosa, Brazil \\ ${ }^{\mathrm{d}}$ School of Agricultural and Veterinary Sciences, São Paulo State University, 14884-900, Jaboticabal, Brazil \\ e Departamento de Entomologia/BIOAGRO, Universidade Federal de Viçosa, 36570-900, Viçosa, Brazil
}

Behroz Khalil Tahmasebi ${ }^{\mathrm{a}}$, Mohammad Taghi Alebrahim ${ }^{\mathrm{a}}$, Rafael A. Roldán-Gómez ${ }^{\mathrm{b}}$, Hellen Martins da Silveira ${ }^{\mathrm{c}}$, Leonardo Bianco de Carvalho ${ }^{\mathrm{d}}$, Ricardo Alcántara-de la Cruz ${ }^{\mathrm{e}, *}$,

\section{A R T I C L E I N F O}

\section{Keywords:}

Alternative weed control

Conyza genus

Chemical control

Glyphosate resistance

Perennial crops

\begin{abstract}
A B S T R A C T
Glyphosate has been applied in European countries for over a decade between rows in olive groves and grape vineyards to control Conyza species [hairy fleabane (C. bonariensis), horseweed (C. canadensis) and Sumatran fleabane (C. sumatrensis)], however poor control has been observed in recent years. Glyphosate susceptible (GS) or resistant (GR) populations were assayed in each species. In addition, Conyza spp. control with alternative herbicides (alone or in mixture with glyphosate) over two years was also assessed. The GS populations of the three species were controlled with glyphosate field doses $\left(1080 \mathrm{~g}^{\mathrm{ae}} \mathrm{ha}^{-1}\right)$. The GR hairy fleabane, horseweed and Sumatran fleabane populations were 15.0, 15.7 and 19.8 times more resistant, respectively, than their respective GS population. The shikimic accumulation of GS populations was 4-6 times higher compared with the GR Conyza populations, confirming the glyphosate resistance of the latter ones. The increase in the glyphosate dose did not control the GR Conyza populations, despite providing a higher dry growth reduction. Glufosinate and flazasulfuron, alone or mixed with glyphosate, were the effective options to control GR and GS populations of hairy fleabane and Sumatran fleabane. However, the GR horseweed population might have evolved multiple resistance to glyphosate and flazasulfuron in Hungary. The other herbicides (PSI, auxinic and PPO) showed an additive effect together with the control provided by glyphosate in the GS and GR populations; however generally, these herbicides could be applied alone at the rosette stage. Effective herbicides with modes of action different from glyphosate, except flazasulfuron for controlling horseweed, should be used to delay the selection of herbicide resistance in perennial crops in Europe.
\end{abstract}

\section{Introduction}

Conyza species [hairy fleabane (C. bonariensis), horseweed (C. canadensis) and Sumatran fleabane (C. sumatrensis)] are common weeds invading a great variety of agronomic crop systems worldwide (Travlos and Chachalis, 2010, 2013), due to their rapid adaptation to undisturbed (non-tillage) and plant-free soils (Brown and Whitwell, 1988). Conyza species have evolved resistance to herbicides in many countries (100 cases), and are listed among the most problematic weeds (Matzrafi et al., 2015; Heap, 2018). Glyphosate is responsible for 13, 42 and 8 cases of resistance in hairy fleabane, horseweed and Sumatran fleabane, respectively, reported in annual and perennial crops, orchards, forests, pastures, roadsides, railways, industrial sites and nurseries around the world (Heap, 2018).

Glyphosate [ $N$-(phosphonomethyl)-glycine] is the world's most successful post-emergence and non-selective herbicide (Duke, 2018). In Spain it has been widely used to control weeds in citrus orchards, olive groves, grape vineyards, and others perennial and annual crops (González-Torralva et al., 2010, 2014), as well as in path borders, railway lines, recreation areas and derelict sites (Urbano et al., 2007). This herbicide is absorbed through leaves and other young-green tissues, and translocated via phloem into meristematic tissues (Preston and Wakelin, 2008). Glyphosate is a potent inhibitor of 5-enolpyruvylshikimate 3-phosphate synthase (EPSPS) by blocking the biosynthesis of phenylalanine, tryptophan, tyrosine and others aromatic compounds in susceptible plants (Maeda and Dudareva, 2012).

\footnotetext{
* Corresponding author.

E-mail address: ricardo.la@ufv.br (R. Alcántara-de la Cruz).
} 
Glyphosate-resistant weeds are able to survive glyphosate exposure due to target-site (mutations in the gene encoding the EPSPS or gene duplication) (Heap and Duke, 2018) or non-target-site (degradation to non-toxic compound, impaired translocation, poor absorption and/or vacuolar compartmentation) (Ghanizadeh and Harrington, 2017) resistance mechanisms, alone or in association (Sammons and Gaines, 2014). The resistant weeds will not be killed by using glyphosate alone.

The herbicide combinations with different modes of action, either in sequential application or tank-mix, can contribute to improve the control of resistant weeds (Tornisielo et al., 2013), and additionally, may also avoid or delay evolution of resistance (Ganie and Jhala, 2017). Improvements in weed control have been observed in glyphosate-resistant species by applying glyphosate tank-mix combinations (Riley and Bradley, 2014), in some cases, the control was improved by 25-30\% compared to glyphosate alone (Eubank et al., 2008).

The objectives were to characterize glyphosate resistant Conyza species, collected in perennial crop systems from different European countries, and to propose alternative chemical strategies for their management.

\section{Material and methods}

\subsection{Plant material and experimental conditions}

Seeds of Conyza species (hairy fleabane, horseweed and Sumatran fleabane) resistant (GR) and susceptible (GS) to glyphosate (Table 1), were planted in plastic containers $(10 \times 10 \mathrm{~cm} \times 6.3 \mathrm{~cm})$ filled with peat moistened and covered with parafilm. Plastic containers were kept in a controlled condition room $\left[28 / 18{ }^{\circ} \mathrm{C}\right.$ (day/night), $16 \mathrm{~h}$ photoperiod, $850 \mathrm{mmol} \mathrm{m}^{-2} \mathrm{~s}^{-1}$ light density and $60 \%$ relative humidity] until germination. Seedlings were transplanted into $250 \mathrm{~cm}^{3}$ pots $(1$ plant pot $\left.^{-1}\right)$ filled with sand/peat $(1: 1 \mathrm{v} / \mathrm{v})$. Pots were placed in the controlled condition room again and watered daily until the herbicide treatments.

Herbicides were applied in a treatment chamber (Devries Manufacturing, Hollandale, Minnesota) equipped with a TeeJet $8002 \mathrm{EVS}$ flat fan nozzle calibrated to deliver $200 \mathrm{~L} \mathrm{ha}^{-1}$ at $200 \mathrm{kPa}$ at a height of $50 \mathrm{~cm}$. Plants with six-eight true leaves (rosette stage or BBCH16-18 stage) were used for the different herbicide treatments.

\subsection{Whole-plant glyphosate dose-response}

The glyphosate (Roundup Energy 45\% w/v, Monsanto, Spain) doses applied on GR and GS Conyza plants were the following: 0, 31.25, 62.5, $125,250,500,1000$ and $2000 \mathrm{~g}_{\text {ae }} \mathrm{ha}^{-1}$. Once treated, the plants were taken to a greenhouse at a temperature regime of $26 / 18{ }^{\circ} \mathrm{C}$ day/night, and watered as necessary. Mortality was recorded 3 weeks after application (WAA), and above-ground biomass was harvested and dried individually in an oven (JP Selecta S.A., Barcelona, Spain) at $75{ }^{\circ} \mathrm{C}$ for $72 \mathrm{~h}$. The experiments had a completely random design using 8 plants per dose and were repeated twice. Plant mortality $(\mathrm{PM}=$ number of dead plants after treatment/total treated plants * 100) and dry weight reduction (DWR) data were expressed in percentage relative to the nontreated control, and submitted to non-linear regression analysis using the following $\log$-logistic equation: $Y=\mathrm{d} / 1+(\mathrm{x} / \mathrm{g})^{\mathrm{b}} \mathrm{c}$ (Ritz et al., 2015).

\subsection{Accumulation of shikimate}

Leaf discs ( $4 \mathrm{~mm}$ in diameter) were taken from young leaves of both GR and GS Conyza plants at the rosette stage to give a total sample of $50 \mathrm{mg}$. Shikimic acid accumulation was determined according to Shaner et al. (2005) using the following glyphosate concentrations: 0 , $10,50,100,500$ and $1000 \mu \mathrm{M}$. Absorbance of samples was measured in a Beckman DU-640 spectrophotometer at $382 \mathrm{~nm}$. The test was performed in triplicate per glyphosate concentration in a completely random design. The shikimic accumulation was determined by constructing a standard curve with known shikimate concentrations. Results were expressed in $\mathrm{mg}$ of shikimic acid $\mu \mathrm{g}^{-1}$ fresh tissue.

\subsection{Alternative chemical control}

Alternative chemical control experiments were carried out in a greenhouse during two cropping seasons (2014-2015 and 2015-2016) in the spring. Ten herbicides were applied alone or in mixture with glyphosate at a single dose (recommended field dose) (Table 2). Conyza seedlings were transplanted in 3-L pots (five plants pot $^{-1}$ ) filled with sand/peat $(1: 1 \mathrm{v} / \mathrm{v})$, kept in the controlled condition room and watered daily until the herbicide treatments. Once treated, pots were taken to the greenhouse and watered as necessary. The experiment had a random block design with 6 repetitions plus a set of control plants for each Conyza species. Both the PM and DWR were assessed as in the dose-response assays 4 WAA, i.e., data were expressed as percentage of untreated controls. The variance stability tests of control rate data showed no difference for both cropping seasons, and data were pooled and subjected to analysis of variance. Differences with $p<0.05$ were considered significant and Tukey's test was conducted for means comparison. Statistical analysis was conducted the Statistix 9.0 software (Analytical Software, Tallahassee).

\section{Results and discussion}

\subsection{Confirmation of glyphosate-resistant populations in Conyza spp.}

Dose-response assays revealed variable glyphosate susceptibility between GR and GS Conyza populations, both in terms of PM and DWR. All GS populations died at the dose recommend to the farmers in European countries in olive groves and vineyards $\left(1080 \mathrm{~g} \mathrm{ha}^{-1}\right)$. On the other hand, the GR populations were not injured at this dose. The resistance indexes $(\mathrm{RI}=\mathrm{R} / \mathrm{S})$ based on the $\mathrm{LD}_{50}(15.2,12.6$ and 8.1) and $\mathrm{DWR}_{50}(15.0,15.7$ and 19.8) values were higher in the GR than the GS populations of hairy fleabane, horseweed and Sumatran fleabane, respectively (Table 3).

Additionally, differential levels of shikimate accumulation were

Table 1

Features of Conyza populations used in this research.

\begin{tabular}{|c|c|c|c|c|c|c|}
\hline Species & Status & Country/Location & Crops & Herbicide application & Dose $_{\text {(years) }}$ & Coordinates \\
\hline \multirow[t]{2}{*}{ C. bonariensis } & Resistant & Spain/Antequera & Orchard & Glyphosate + Auxinic synthetic & ${ }^{\mathrm{a}} 1080_{(10)}+{ }^{\mathrm{b}} 400_{(5)}$ & $37.057224,-4.515618$ \\
\hline & Susceptible & Spain/Antequera & Railway & Mechanical control & $\mathrm{NH}$ & $37.058480,-4.504785$ \\
\hline \multirow[t]{2}{*}{ C. canadensis } & Resistant & Hungary/Badacsony & Vineyard & Glyphosate + ALS inhibitor & ${ }^{\mathrm{a}} 1800_{(20)}+{ }^{\mathrm{c}} 750_{(7)}$ & $46.790435,-17.490739$ \\
\hline & Susceptible & Hungary/Balaton & No crop & Mechanical control & $\mathrm{NH}$ & $48.085674,-20.303097$ \\
\hline \multirow[t]{2}{*}{ C. sumatrensis } & Resistant & France/Mazan & Vineyard & Glyphosate & ${ }^{\mathrm{a}} 1080_{(15)}$ & $44.047650,-5.129497$ \\
\hline & Susceptible & France/Mazan & Vineyard & Organic crop & $\mathrm{NH}$ & $44.069471,-5.153672$ \\
\hline
\end{tabular}

\footnotetext{
a Glyphosate $g$ ae ha ${ }^{-1}$.

b $2,4-\mathrm{D}$ ae ha ${ }^{-1}$.

c Flazasulfuron $\mathrm{g}$ ai ha ${ }^{-1}$; subscript of years $=$ application history of the respective herbicide at the indicated dose, $\mathrm{NH}=$ no history of herbicide application.
} 
Table 2

Main characteristics of herbicides used in this research.

\begin{tabular}{|c|c|c|c|c|c|}
\hline Herbicide $^{\mathrm{a}}$ & Trade name & Group $^{\mathrm{b}}$ & $\mathrm{MoA}^{\mathrm{c}}$ & $\begin{array}{l}\text { Rate }(\mathrm{g} \\
\text { ai } \\
\left.\text { ha }^{-1}\right)^{\mathrm{d}}\end{array}$ & Application time \\
\hline Glyphosate & $\begin{array}{l}\text { Roundup } \\
\text { Energy }\end{array}$ & $9 / G$ & EPSPS & 1080 & postemergence \\
\hline 2,4-D & $\mathrm{U}-46 \mathrm{D}^{\circ}$ & $4 / 0$ & Auxinic & 720 & postemergence \\
\hline Fluroxypyr & Starane $20^{\circ}$ & $4 / 0$ & Auxinic & 300 & postemergence \\
\hline MCPA & Ajax & $4 / \mathrm{O}$ & Auxinic & 750 & postemergence \\
\hline $\begin{array}{l}\text { Carfentrazone- } \\
\text { ethyl }\end{array}$ & $\begin{array}{l}\text { Affinity } \\
240\end{array}$ & $14 / \mathrm{E}$ & PPO & 24 & $\begin{array}{l}\text { early } \\
\text { postemergence }\end{array}$ \\
\hline Flumioxazin & Sumisoya") & $14 / \mathrm{E}$ & PPO & 150 & $\begin{array}{l}\text { early } \\
\text { postemergence }\end{array}$ \\
\hline Oxyfluorfen & Goald $^{\circ}$ & $14 / \mathrm{E}$ & PPO & 240 & $\begin{array}{l}\text { pre and } \\
\text { postemergence }\end{array}$ \\
\hline Pyraflufen-ethyl & Gozai $^{\circ}$ & $14 / \mathrm{E}$ & PPO & 8 & postemergence \\
\hline Diquat & AYCLOD $^{\circ}$ & $22 / \mathrm{D}$ & PSI & 400 & postemergence \\
\hline Flazasulfuron & Terafit $^{\circ}$ & $2 / \mathrm{B}$ & ALS & 50 & $\begin{array}{l}\text { pre and } \\
\text { postemergence }\end{array}$ \\
\hline Glufosinate & Finale $^{\circ}$ & $10 / \mathrm{H}$ & GS & 750 & postemergence \\
\hline
\end{tabular}

a Glyphosate given in g equivalent acid from monopotassium salt (equivalent to $1460 \mathrm{~g}_{\text {ia }} \mathrm{ha}^{-1}$ ).

b Herbicide group according to the Weed Science Society of America and the Herbicide Resistance Action Committee (WSSA/HRAC).

c Mechanism of action: inhibitors of enolpyruvyl shikimate-3-phosphate synthase (EPSPS), synthetic auxins, protoporphyrinogen oxidase (PPO), photosystem I (PSI), acetolactate synthase (ALS), and glutamine synthetase (GS).

d Field dose in Spain.

observed in the three Conyza species. The GS populations of hairy fleabane, horseweed and Sumatran fleabane accumulated 6.2, 4.7 and 4.1 times more shikimate, respectively, in relation to the GR populations (Fig. 1).

Similar results concerning differential dose-response and shikimate accumulation levels were observed in GR populations of hairy fleabane (Dinelli et al., 2008; Kleinman et al., 2016), horseweed (Tani et al., 2015; Kleinman et al., 2016) and Sumatran fleabane (GonzálezTorralva et al., 2014) in comparison to GS populations of these species. Resistance indices ranging from 6 to 30 were observed in glyphosate resistant Conyza species (González-Torralva et al., 2012, 2014; Tani et al., 2015; Kleinman et al., 2016). After glyphosate exposure, shikimate accumulates in both GS and GR plants of Conyza species (Mueller et al., 2003); however, this accumulation occurs at lowest rates in the GR plants (Kleinman and Rubin, 2017). Therefore, the low accumulation of shikimate in the GR populations of hairy fleabane, horseweed

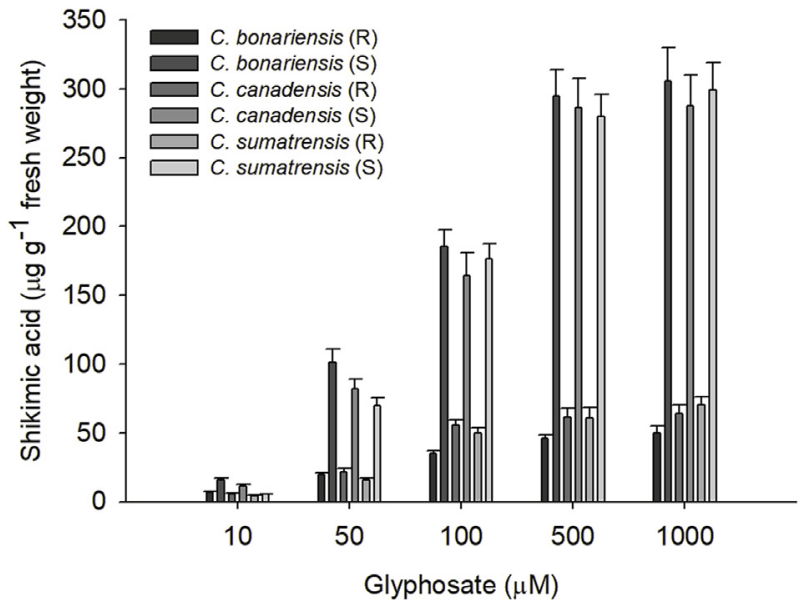

Fig. 1. Accumulation of shikimate in glyphosate-resistant (R) and -susceptible (S) populations of Conyza species exposed to increasing glyphosate concentrations. Vertical bars \pm standard error $(n=3)$.

and Sumatran fleabane may show that the EPSPS enzyme had a lower sensitivity to glyphosate (Dominguez-Valenzuela et al., 2017). Therefore, our results confirm resistance to glyphosate in the $\mathrm{R}$ populations of Conyza species studied.

\subsection{Chemical control of glyphosate-resistant populations of Conyza species}

Glyphosate field dose (1080 $\mathrm{g}$ ae $\mathrm{ha}^{-1}$ ) gave poor PM of the GR hairy fleabane, horseweed and Sumatran fleabane populations, despite killing the respective GS populations by $100,87.5$ and $100 \%$. The result was similar when the double-field dose $\left(2160 \mathrm{~g}_{\text {ae }} \mathrm{ha}^{-1}\right)$ was used. Therefore, the increase in glyphosate dose was not an alternative for GR Conyza species control despite providing better DWR of up to $50 \%$, depending on the species (Figs. 2 and 3). Similar results were observed in Eleusine indica and Paspalum distichum (Alcántara et al., 2016), or Leptochloa virgata (Pérez-López et al., 2014) in citrus orchards from Spain and Mexico, respectively.

Carfentrazone-ethyl (24 $\mathrm{g}$ ai ha ${ }^{-1}$ ), flumioxazin (150 $\mathrm{g}$ ai ha $\left.{ }^{-1}\right)$, and oxyfluorfen (240 $\mathrm{g}$ ai $\mathrm{ha}^{-1}$ ) sprayed alone provided low DWR $(<40 \%)$ and did not cause PM in either the GR or GS Conyza species populations. When these herbicides were applied in mixture with glyphosate $\left(1080 \mathrm{~g}_{\text {ae }} \mathrm{ha}^{-1}\right)$, the GS populations were controlled; meanwhile, DWR increased substantially in the GR populations but without

Table 3

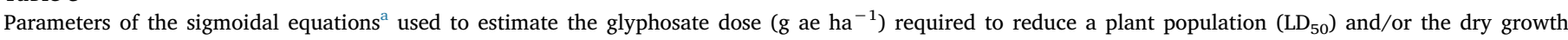
reduction $\left(\mathrm{DWR}_{50}\right)$ by $50 \%$ in glyphosate-resistant (GR) and -susceptible (GS) populations of Conyza species.

\begin{tabular}{|c|c|c|c|c|c|c|c|}
\hline Species & Population & $\mathrm{d}$ & $\mathrm{b}$ & $\mathrm{R}^{2}$ & Mean dose $\left(\mathrm{g}\right.$ ae ha $\left.{ }^{-1}\right)$ & $\mathrm{RI}^{\mathrm{b}}$ & P-value \\
\hline \multicolumn{8}{|c|}{ Plant survival $\left(\mathrm{LD}_{50}\right)$} \\
\hline \multirow[t]{2}{*}{ C. bonariensis } & $\mathrm{R}$ & 99.65 & 2.15 & 0.99 & $4985.0 \pm 102.8$ & 15.2 & 0.0001 \\
\hline & $S$ & 98.48 & 2.75 & 0.98 & $327.2 \pm 6.7$ & & \\
\hline \multirow[t]{2}{*}{ C. canadensis } & $\mathrm{R}$ & 99.43 & 2.95 & 0.99 & $3258.6 \pm 92.8$ & 12.6 & 0.0001 \\
\hline & $\mathrm{S}$ & 101.12 & 3.06 & 0.98 & $257.9 \pm 7.3$ & & \\
\hline \multirow[t]{2}{*}{ C. sumatrensis } & $\mathrm{R}$ & 99.98 & 2.65 & 0.97 & $3146.9 \pm 103.0$ & 8.1 & 0.0001 \\
\hline & $S$ & 99.72 & 3.29 & 0.99 & $388.9 \pm 21.8$ & & \\
\hline \multicolumn{8}{|c|}{ Growth reduction $\left(\mathrm{DWR}_{50}\right)$} \\
\hline \multirow[t]{2}{*}{ C. bonariensis } & $\mathrm{R}$ & 99.34 & 1.46 & 0.98 & $1129.9 \pm 62.4$ & 15.0 & 0.0001 \\
\hline & $S$ & 101.43 & 2.49 & 0.99 & $75.2 \pm 5.2$ & & \\
\hline \multirow[t]{2}{*}{ C. canadensis } & $\mathrm{R}$ & 100.15 & 2.28 & 0.98 & $975.5 \pm 51.4$ & 15.7 & 0.0001 \\
\hline & $\mathrm{S}$ & 99.37 & 3.26 & 0.99 & $62.3 \pm 5.2$ & & \\
\hline \multirow[t]{2}{*}{ C. sumatrensis } & $\mathrm{R}$ & 101.92 & 2.13 & 0.97 & $718.1 \pm 35.4$ & 19.8 & 0.0001 \\
\hline & $S$ & 98.05 & 3.73 & 0.98 & $36.3 \pm 5.9$ & & \\
\hline
\end{tabular}

${ }^{\text {a }} \mathrm{Y}=\mathrm{d} / 1+(\mathrm{x} / \mathrm{g})^{\mathrm{b}}$; where $Y$ is survival or dry weight expressed as a percentage of the non-treated control, $d$ is the upper limits of the curve, $b$ is the slope of the curve at the inflection point, $g$ the herbicide rate at the inflection point (i.e., $\mathrm{LD}_{50}$ or $\mathrm{DWR}_{50}$ ), and $x$ (independent variable) is the herbicide rate.

${ }^{\text {b }} \mathrm{RI}=$ resistant index, calculated as $\mathrm{LD}_{50}(\mathrm{R}) / \mathrm{LD}_{50}(\mathrm{~S})$ or $\mathrm{DWR}_{50}(\mathrm{R}) / \mathrm{DWR}_{50}(\mathrm{~S})$. \pm Standard error of the mean $(\mathrm{n}=8)$. 

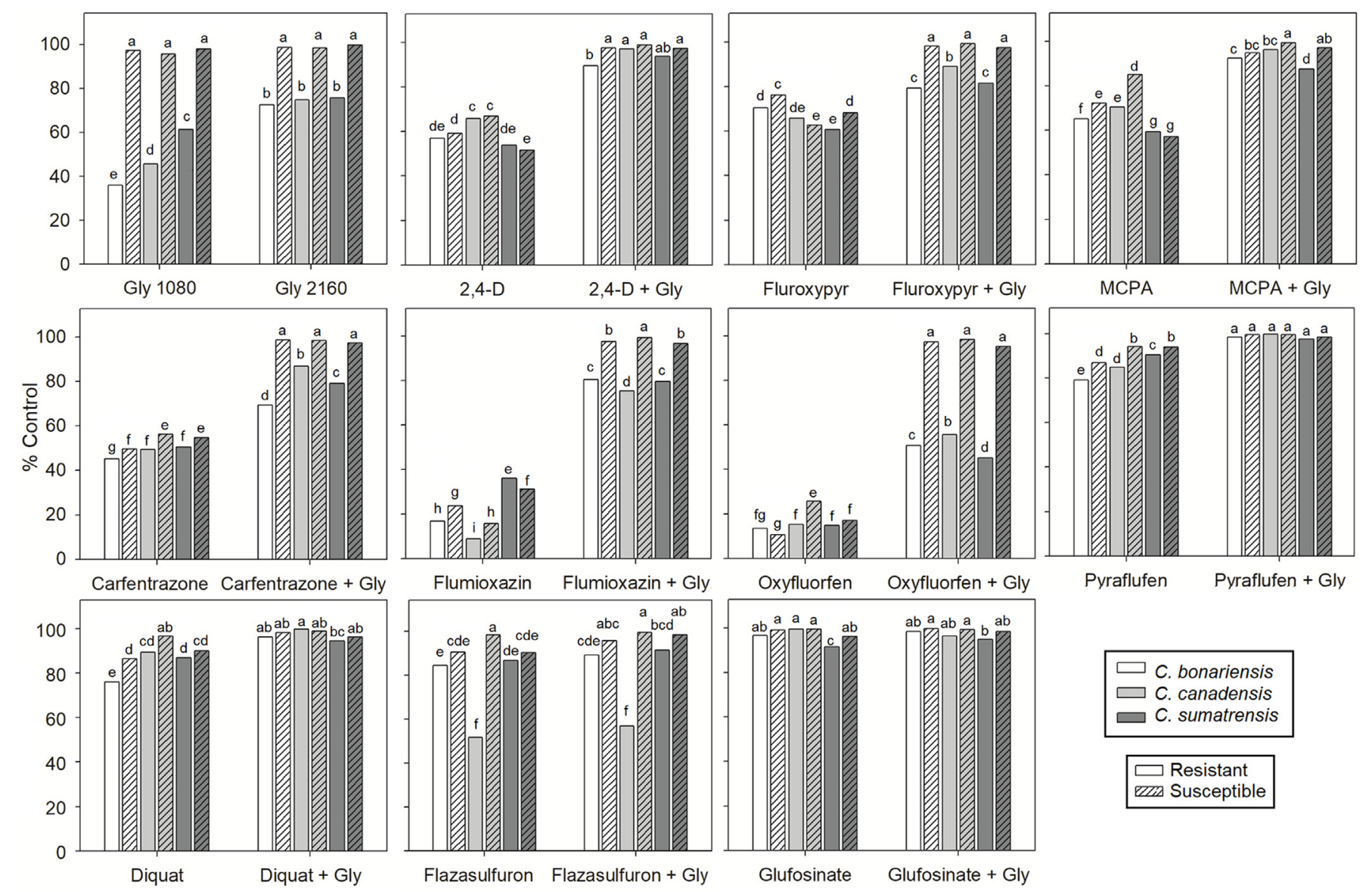

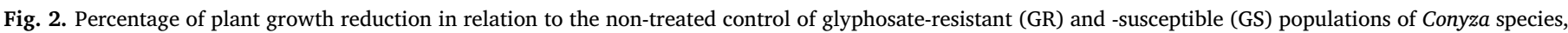

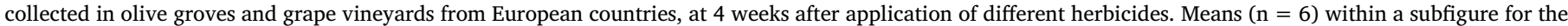

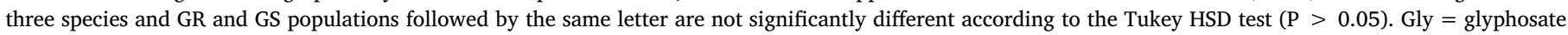

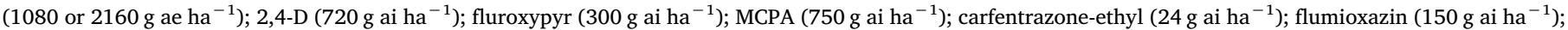

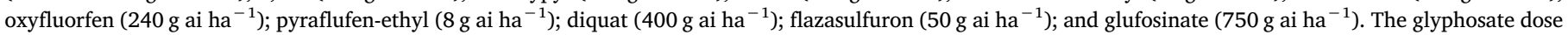
was $1080 \mathrm{~g}$ ae ha ${ }^{-1}$ when the herbicides were applied in mixture (+Gly).

causing PM (Figs. 2 and 3).

Fluroxypyr (200 $\left.\mathrm{g}_{\text {ai }} \mathrm{ha}^{-1}\right)$, MCPA (750 $\mathrm{g}$ ai ha $\left.{ }^{-1}\right)$ and 2,4-D (720 g ai ha ${ }^{-1}$ ) alone provided intermediate control levels (greater than $50 \%$ but less than 80\%) in both GR and GS Conyza species populations, however they did not cause PM $(<12.5 \%)$. In mixture with glyphosate, they controlled the GS populations, but the PM of GR populations was no higher than $25 \%$ with fluroxypyr and MCPA. The mixture 2,4D + glyphosate led to DWR of above $87 \%$ for both GS and GR hairy fleabane and Sumatran fleabane populations. However, this mixture only controlled up to $75 \%$ of the GR horseweed population, despite reducing its DWR by $>90 \%$ (Figs. 2 and 3).

Diquat ( $400 \mathrm{~g}$ ai ha ${ }^{-1}$ ), glufosinate $\left(750 \mathrm{~g}\right.$ ai ha ${ }^{-1}$ ) and pyraflufenethyl $\left(8 \mathrm{~g}\right.$ ai ha $\left.{ }^{-1}\right)$, either alone or mixed with glyphosate $(1080 \mathrm{~g}$ ae $\mathrm{ha}^{-1}$ ), provided high DWR ( $>80 \%$ ) in both GS and GR Conyza species populations. Diquat and glufosinate alone showed high control levels causing PM by $>70 \%$. However, pyraflufen-ethyl alone did not effectively kill the plants of either GS or GR Conyza populations with $45-90 \%$ depending on the species, surviving. In all three cases, PM was greater than $95 \%$ when the herbicides were mixed with glyphosate (Figs. 2 and 3).

Flazasulfuron ( $50 \mathrm{~g}$ ai ha ${ }^{-1}$ ), alone or combined with glyphosate $\left(1080 \mathrm{~g}\right.$ ae ha $\left.{ }^{-1}\right)$, provided a good control (> 85\%) of both GS and GR Conyza populations reducing the DWR by $>80 \%$, except for the GR horseweed population. Even, the mixture of flazasulfuron plus glyphosate did not cause PM in more than 7\% of this population (Figs. 2 and 3).
The rapid resistance evolution to glyphosate highlights the relevance of implementing different weed management strategies (Ganie and Jhala, 2017). In general, the mixtures of the alternative herbicide with glyphosate showed additive effects, because synergistic interactions between agrochemicals are rare (Cedergreen, 2014), and it is more common to observe antagonistic effects of glyphosate mixed with herbicides, such as atrazine, cloransulam, dicamba, lactofen, and topramezone (Vidal et al., 2003; Harre et al., 2018). Additive effects were observed in most mixtures, and explain why those herbicides that showed lower (carfentrazone-ethyl, flumioxazin and oxyfluorfen) or intermediate (fluroxypyr, MCPA and 2,4-D) control in GR Conyza species when they were applied alone, continued to show inefficient control when applied in mixture with glyphosate, since the control increase observed with the mixtures of these herbicides was proportional to that obtained by glyphosate alone.

In contrast, the control provided by diquat, flazasulfuron (except for the GR horseweed population), glufosinate and pyraflufen-ethyl applied in isolation provided good control in GR Conyza species populations, and their mixture with glyphosate significantly improved control. These herbicides are often reported as having acceptable control levels when resistance to their action mechanisms has not evolved (Eubank et al., 2008; Chahal and Johnson, 2012; Singh et al., 2012; Pérez-López et al., 2014; Riley and Bradley, 2014; Alcántara et al., 2016). However, the ineffective control provided by the mixture of flazasulfuron plus glyphosate on the GR horseweed, suggests that this population may possess multiple resistance to flazasulfuron and glyphosate, because in general 


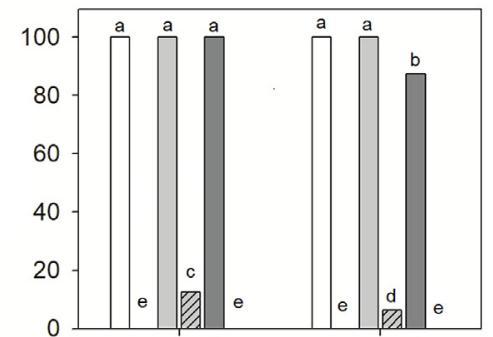

Gly 1080
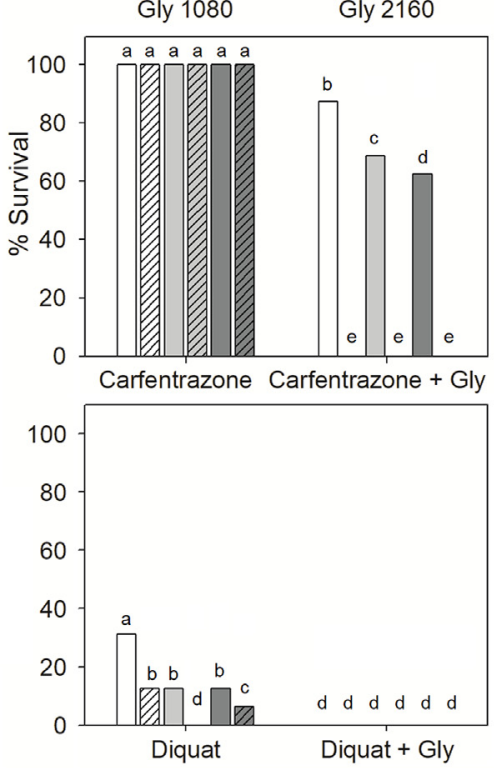

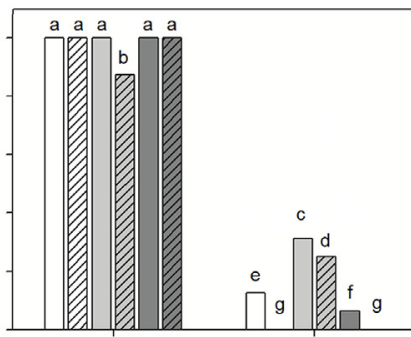

2,4-D
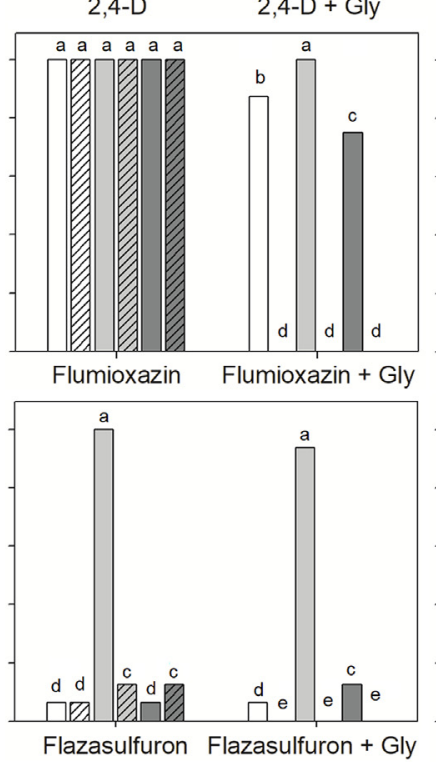

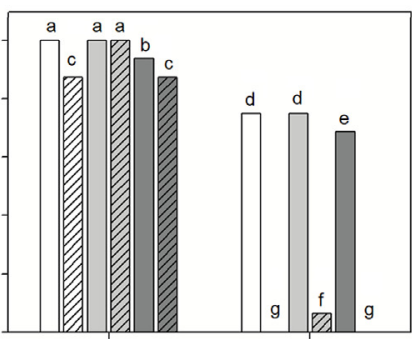

Fluroxypyr

Fluroxypyr + Gly
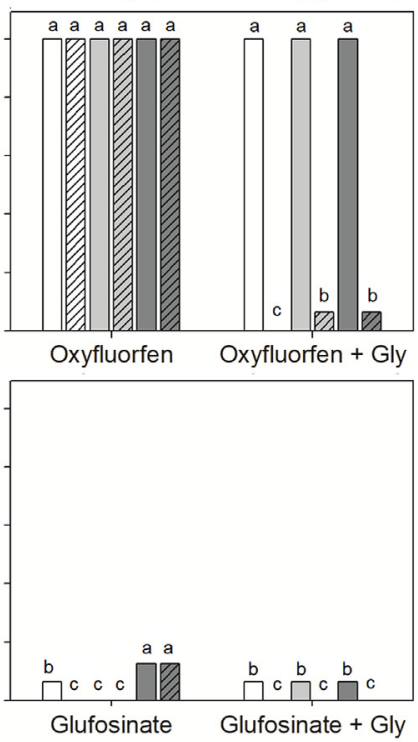

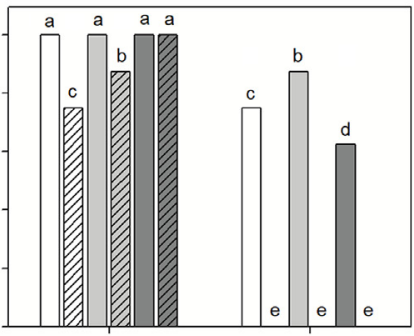

MCPA

MCPA + Gly
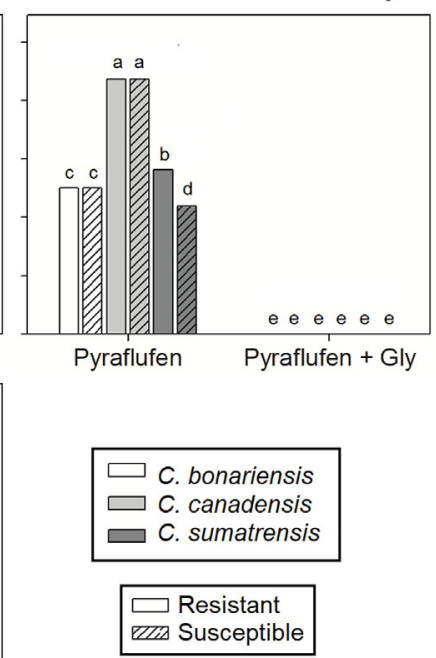

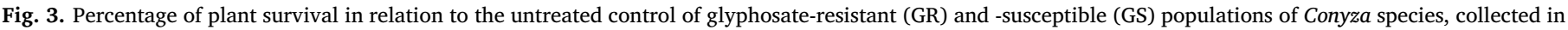

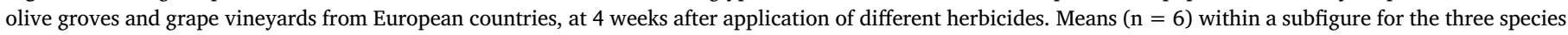

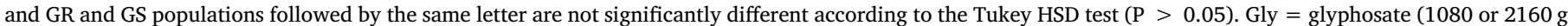

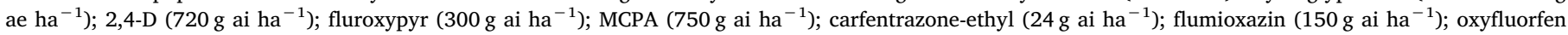

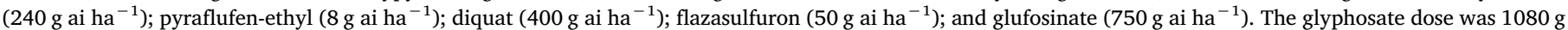
ae ha ${ }^{-1}$ when the herbicides were applied in mixture (+ Gly).

this mixture presents good weed control in perennial crops (Singh et al., 2012). Therefore, it might be the first case of multiple resistance to these herbicides in Hungary.

\section{Conclusion}

Dry weight reduction estimates, weed survival and shikimate accumulation confirm the resistance between Conyza species populations collected from those sites with glyphosate history applications (GR) compared to sites never treated (GS). One horseweed population might have evolved multiple resistance to glyphosate and flazasulfuron in Hungary. Diquat, flazasulfuron (except for the GR horseweed population), glufosinate and pyraflufen-ethyl, herbicides with different mechanisms of action (PSI, ALS, GS, and PPO inhibitors, respectively) from glyphosate (EPSPS inhibitor), should be used, alone or combined with glyphosate, to delay selection for herbicide resistance in perennial crops from Europe.

\section{Acknowledgements}

This work was funded by the Asociación Agroquímicos y Medio Ambiente (Spain). Dr. Phillip Villani (The University of Melbourne) revised and corrected the English language used in this manuscript.

\section{References}

Alcántara, R., Fernandez, P., Smeda, R.J., Alves, P.L., Prado, R., 2016. Response of Eleusine indica and Paspalum distichum to glyphosate following repeated use in citrus groves. Crop Protect. 79, 1-7. http://dx.doi.org/10.1016/j.cropro.2015.09.027.

Brown, S.M., Whitwell, T., 1988. Influence of tillage on horseweed (Conyza canadensis). Weed Technol. 2, 269-270. http://dx.doi.org/10.1017/S0890037X00030566.

Chahal, G.S., Johnson, W.G., 2012. Influence of glyphosate or glufosinate combinations with growth regulator herbicides and other agrochemicals in controlling glyphosateresistant weeds. Weed Technol. 26, 638-643. http://dx.doi.org/10.1614/WT-D-1200058.1.

Cedergreen, N., 2014. Quantifying synergy: a systematic review of mixture toxicity studies within environmental toxicology. PLoS One 9, e96580. http://dx.doi.org/10. 1371/journal.pone.0096580.

Dinelli, G., Marotti, I., Bonetti, A., et al., 2008. Physiological and molecular basis of glyphosate resistance in Conyza bonariensis (L.) Cronq biotypes from Spain. Weed Res. 48, 257-265. http://dx.doi.org/10.1111/j.1365-3180.2008.00623.x.

Dominguez-Valenzuela, J.A., Gherekhloo, J., Fernández-Moreno, P.T., et al., 2017. First confirmation and characterization of target and non-target site resistance to glyphosate in Palmer amaranth (Amaranthus palmeri) from Mexico. Plant Physiol. Biochem. 115, 212-218. http://dx.doi.org/10.1016/j.plaphy.2017.03.022.

Duke, S.O., 2018. The history and current status of glyphosate. Pest Manag. Sci. 74, 1027-1034. http://dx.doi.org/10.1002/ps. 4652.

Eubank, T.W., Poston, D.H., Nandula, V.K., et al., 2008. Glyphosate-resistant horseweed (Conyza canadensis) control using glyphosate, paraquat, and glufosinate-based herbicide programs. Weed Technol. 22, 16-21. http://dx.doi.org/10.1614/WT-07-038. 1. 2008.

Ganie, Z.A., Jhala, A.J., 2017. Interaction of 2,4-D or dicamba with glufosinate for control of glyphosate-resistant giant ragweed (Ambrosia trifida L.) in glufosinate-resistant maize (Zea mays L. Front. Plant Sci. 8, 1207. http://dx.doi.org/10.3389/fpls.2017. 01207.

Ghanizadeh, H., Harrington, K.C., 2017. Non-target site mechanisms of resistance to herbicides. Crit. Rev. Plant Sci. 36, 24-34. http://dx.doi.org/10.1080/07352689. 2017.1316134.

Gonzalez-Torralva, F., Gil-Humanes, J., Barro, F., Dominguez-Valenzuela, J.A., De Prado, R., 2014. First evidence for a target site mutation in the EPSPS2 gene in glyphosateresistant Sumatran fleabane from citrus orchards. Agron. Sustain. Dev. 34, 553-560. http://dx.doi.org/10.1007/s13593-013-0163-8.

González-Torralva, F., Cruz-Hipolito, H., Bastida, F., et al., 2010. Differential susceptibility to glyphosate among the Conyza weed species in Spain. J. Agric. Food Chem. 
58, 4361-4366. http://dx.doi.org/10.1021/jf904227p.

González-Torralva, F., Rojano-Delgado, A.M., Luque, M.D., Mülleder, N., De Prado, R. 2012. Two non-target mechanisms are involved in glyphosate-resistant horseweed (Conyza canadensis L. Cronq.) biotypes. J. Plant Physiol. 169, 1673-1679. http://dx. doi.org/10.1016/j.jplph.2012.06.014.

Harre, N.T., Young, J.M., Young, B.G., 2018. Glyphosate-induced antagonism in rapid response giant ragweed (Ambrosia trifida). Weed Technol. 32, 52-59. http://dx.doi. org/10.1017/wet.2017.92.

Heap, I., Duke, S.O., 2018. Overview of glyphosate-resistant weeds worldwide. Pest Manag. Sci. 74, 1040-1049. http://dx.doi.org/10.1002/ps. 4760.

Heap, I., 2018. International survey of herbicide resistant weeds. http://www. weedscience.org/, Accessed date: 16 May 2018.

Kleinman, Z., Ben-Ami, G., Rubin, B., 2016. From sensitivity to resistance - factors af fecting the response of Conyza spp. to glyphosate. Pest Manag. Sci. 72, 1681-1688. http://dx.doi.org/10.1002/ps.4187.

Kleinman, Z., Rubin, B., 2017. Non-target-site glyphosate resistance in Conyza bonariensisis based on modified subcellular distribution of the herbicide. Pest Manag. Sci. 73, 1246-1253. http://dx.doi.org/10.1002/ps.4293.

Maeda, H., Dudareva, N., 2012. The shikimate pathway and aromatic amino acid biosynthesis in plants. Annu. Rev. Plant Biol. 63, 73-105. http://dx.doi.org/10.1146/ annurev-arplant-042811-105439.

Matzrafi, M., Lazar, T.W., Sibony, M., Rubin, R., 2015. Conyza species: distribution and evolution of multiple target-site herbicide resistances. Planta 242, 259-267. http:// dx.doi.org/10.1007/s00425-015-2306-4.

Mueller, T.C., Massey, J.H., Hayes, R.M., Main, C.L., Stewart, C.N., 2003. Shikimate accumulates in both glyphosate-sensitive and glyphosate-resistant horseweed (Conyza canadensis L. Cronq.). J. Agric. Food Chem. 51, 680-684. http://dx.doi.org/10.1021/ jf026006k.

Pérez-López, M., González-Torralva, F., Cruz-Hipólito, H.E., et al., 2014. Characterization of glyphosate-resistance tropical sprangletop (Leptochloa virgata) and its alternative chemical control in Persian lime. Weed Sci. 62, 441-450. http://dx.doi.org/10.1614/ WS-D-13-00177.1.

Preston, C., Wakelin, A.M., 2008. Resistance to glyphosate from altered herbicide translocation patterns. Pest Manag. Sci. 64, 372-376. http://dx.doi.org/10.1002/ps.
1489.

Riley, R.B., Bradley, K.W., 2014. Influence of application timing and glyphosate tank-mix combinations on the survival of glyphosate-resistant giant ragweed (Ambrosia trifida) in soybean. Weed Technol. 28, 1-9. http://dx.doi.org/10.1614/WT-D-13-00098.1.

Ritz, C., Baty, F., Streibig, J.C., Gerhard, D., 2015. Dose-response analysis using R. PLoS One 10, e0146021. http://dx.doi.org/10.1371/journal.pone.0146021.

Sammons, R.D., Gaines, T.A., 2014. Glyphosate resistance: state of knowledge. Pest Manag. Sci. 70, 1367-1377. http://dx.doi.org/10.1002/ps.3743.

Shaner, D.L., Nadler-Hassar, T., Henry, W.B., Koger, C.H., 2005. A rapid in vivo shikimate accumulation assay with excised leaf discs. Weed Sci. 53, 769-774. http://dx.doi. org/10.1614/WS-05-009R.1.

Singh, M., Ramirez, A.H.M., Jhala, A.J., Malik, M., 2012. Weed control efficacy and citrus response to flazasulfuron applied alone or in combination with other herbicides. Am. J. Plant Sci. 3, 520-527. http://dx.doi.org/10.4236/ajps.2012.34062.

Tani, E., Chachalis, D., Travlos, I., 2015. A glyphosate resistance mechanism in Conyza canadensis involves synchronization of EPSPS and ABC-transporter genes. Plant Mol. Biol. Rep. 33, 1721-1730. http://dx.doi.org/10.1007/s11105-015-0868-8.

Tornisielo, V.L., Botelho, R.G., Alves, P.A.T., Bonfleur, E.J., Monteiro, S.H., 2013. Pesticide tank mixes: an environmental point of view. In: Price, A. (Ed.), Herbicides Current Research and Case Studies in Use. InTech, pp. 473-487. http://dx.doi.org/ $10.5772 / 55948$.

Travlos, I.S., Chachalis, D., 2010. Glyphosate-resistant hairy fleabane (Conyza bonariensis) is reported in Greece. Weed Technol. 24, 569-573. http://dx.doi.org/10.1614/WT-D09-00080.1.

Travlos, I.S., Chachalis, D., 2013. Relative competitiveness of glyphosate-resistant and glyphosate-susceptible populations of hairy fleabane, Conyza bonariensis. J. Pest. Sci. 86, 345-351. http://dx.doi.org/10.1007/s10340-012-0446-x.

Urbano, J.M., Borrego, A., Torres, V., et al., 2007. Glyphosate-resistant hairy fleabane (Conyza bonariensis) in Spain. Weed Technol. 21, 396-401. http://dx.doi.org/10. 1614/WT-06-096.1.

Vidal, R.A., Machry, M., Hernandes, G.C., Fleck, N.G.I., 2003. Antagonism with glyphosate and triazine combinations. Plant. Danihna 21, 301-306. http://dx.doi.org/10. 1590/S0100-83582003000200016. 